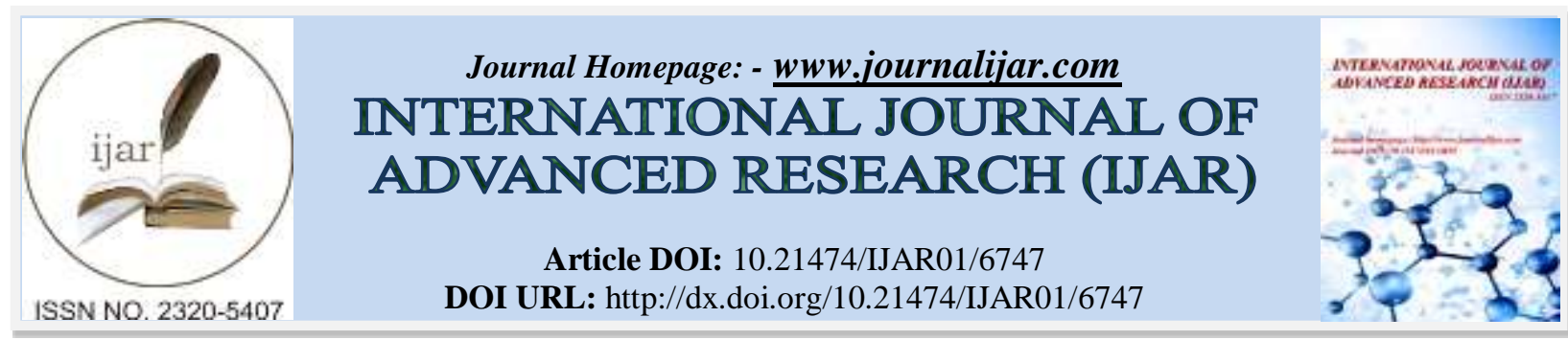

RESEARCH ARTICLE

\title{
ANTHROPOMETRIC MEASUREMENT OF FOOT LENGTH AND ITS RELATION TO STATURE IN JAMMU AND KASHMIR POPULATION.
}

\author{
Afshan Saleem ${ }^{1}$, Rachna Magotra ${ }^{2}$, Saima Rashid ${ }^{2}$ and Shazia Gul ${ }^{2}$. \\ 1. Deptt of Anatomy, GMC Jammu, University of Jammu, India. \\ 2. Deptt of Anatomy, GMC Jammu, University of Jammu, India.
}

\section{Manuscript Info}

Manuscript History

Received: 15 January 2018

Final Accepted: 17 February 2018

Published: March 2018

Keywords:-

foot Length, Anthropometry.

\section{Abstract}

Aim: The aim of present study was to find a relation between foot length and stature and to show if height could be predicted from foot length measurements in J\&K (JAMMU AND KASHMIR) population.

Methodology: A sample of 200 medical students (100 males and 100 females) between the age group of 18-25 years were taken up for this study All the measurements were taken at a fixed time of day, to eliminate diurnal variation. Anthropometric measurement i.e, foot length was measured separately on left and right side of each individual. Complete stature of each individual was measured.

Results: The statistical analysis indicated that the correlation between stature and parameter i.e, foot length studied in males and females was positively and statistically highly significant. Thus the present study indicates a positive correlation between individual's foot length and the stature.

Copy Right, IJAR, 2018,. All rights reserved.

\section{Introduction:-}

Identification is the birth right of an individual. To identify a person, age, sex, stature and race are the main four pillars. Extensive research has been done to establish these pillars of identity from various parameters of the body. So, anthropometry helps us in the reconstruction of biological profile of the deceased i.e, the age, sex, ethnicity and stature. Among these "big fours" of the forensic anthropology, estimation of stature is considered as one of the main parameters of personal identification. It is one of the most important and useful anthropometric parameter determining physical identity of an individual (Agrawal J et al, 2013) ${ }^{\mathbf{1}}$.

Stature is the natural height of a person in upright position. Stature provides an insight into various features of a population like nutrition, health, genetic make-up, geographical location, environment and climatic condition. The stature of an individual is an inherent characteristic, the estimation of which is considered to be an important assessment in the identification of unknown human remains. The stature is a very sensitive trait that depends on age, sex, body composition, social strata and secular trends (Kozak J, 1996) ${ }^{2}$.

In the past, scientists have used several bones of human skeleton ranging from small bones to fragments of long bones for identification, but in recent times, foot is the focus of attention for identification. Forensic identification from foot or its parts is important as there is increased likelihood of its recovery from the disaster site (often enclosed in shoes). Also, foot is mostly separated from body in cases such as high power explosion, bomb blasts, airplane crashes and other high impact transportation accidents. For this, forensic podiatry plays an important role 
which is a sub division of forensic science dealing with the identification of a person from foot. Vernon DW $\boldsymbol{B}$ McCourt FJ, $\mathbf{1 9 9 9}^{3}$ stated that forensic podiatrists apply their experience and sound podiatric knowledge in forensic investigations, to show the association of an individual to the scene of crime and answer any legal question regarding foot or footwear.

Ossification and maturation in the foot occur earlier than the long bones and therefore height could be more accurately predicted from foot measurements as compared to long bones in adolescence (Parekh U et al, 2014) ${ }^{\mathbf{4}}$.

\section{Aim \& objectives:-}

The aim of our study was to measure foot length and stature of a sample of population from Jammu and Kashmir State and to find out the correlation between these two measurements.

\section{Methodology:-}

Anthropometric measurements i.e, foot length which is the distance from the most prominent part of heel to the most distal part of toe (greater or second toe) was measured and foot breadth i.e, the distance between the most prominent point on the medial aspect of head of first metatarsal and the most prominent point on lateral aspect of head of fifth metatarsal were measured separately on left and right side of each individual using sliding vernier caliper. Complete stature of each individual was measured. It is the vertical distance between highest point on vertex and the platform of stadiometer. The subject should stand erect, barefooted on a level platform against the stadiometer bar with his back and hips touching the bar.The feet should touch each other and the heel should touch the bar and arms hanging by the side. The head of the subject should rest without any strain in the eye-ear plane or Frankfurt plane i.e tragion and the infraorbital margin of both the sides must lie in same plane.

\section{OBSERVATION AND RESULTS:}

Table 1:- Statistical data of Height and foot length in Males.

\begin{tabular}{|l|l|l|l|c|c|}
\cline { 2 - 6 } \multicolumn{1}{c|}{ DIMENSIONS } & MEAN & SD & t-VALUE & p-VALUE \\
\hline $\begin{array}{c}\text { STATURE } \\
\text { Right foot } \\
\text { length (RFL) }\end{array}$ & 173.76 & 7.32 & 15.07 & .432 & $<.001$ \\
\hline $\begin{array}{l}\text { Left foot } \\
\text { length (LFL) }\end{array}$ & 26.01 & 1.001 & .667 & $<.001$ \\
\hline
\end{tabular}

Table 2:- Statistical data of Height and foot length in Females.

\begin{tabular}{|c|c|c|c|c|c|}
\hline & \multirow{2}{*}{\begin{tabular}{|c|} 
DIMENSIONS \\
STATURE \\
\end{tabular}} & \multirow{2}{*}{$\begin{array}{r}\text { MEAN } \\
158.97\end{array}$} & \multirow{2}{*}{$\begin{array}{c}\text { SD } \\
6.13\end{array}$} & \multirow{2}{*}{$\begin{array}{r}\text { t-VALUE } \\
15.07\end{array}$} & p-VALUE \\
\hline & & & & & $<.001$ \\
\hline & \begin{tabular}{|l} 
Right \\
length
\end{tabular} & 23.35 & 1.11 & 16.30 & $<.001$ \\
\hline & $\begin{array}{r}\text { Left foot } \\
\text { length ( LFL) }\end{array}$ & 23.22 & 1.08 & 17.34 & $<.001$ \\
\hline
\end{tabular}

\section{Discussion:-}

The present study was done to see any correlation between foot length and stature. There are various methods to estimate stature from bones, but the easiest and reliable method is by regression analysis. Measurements of foot length of both the right and left side were taken. The prediction function was derived through linear regression equations from foot length of both males and females separately.

In the present study, the mean stature was $173.36 \mathrm{cms}(\mathrm{SD} \pm 7.32)$ in males and $158.97 \mathrm{cms}(\mathrm{SD} \pm 6.13)$ in females. The males were found to be significantly taller compared to females. This could be because of the overall larger bony structure of males. Our results were similar to a study done by Kautilya VD et $\mathbf{~ a l}^{\mathbf{5}}, \mathbf{2 0 1 3}$ who found that males were significantly taller than females with a mean stature being $172 \mathrm{cms}$ in males as compared to $159 \mathrm{cms}$ in females. Similarly, Rani M et $\mathbf{a l}^{\mathbf{6}}, \mathbf{2 0 1 1}$ also did a study on medical students aged 18-22 years and found that males were taller than females. The mean value of stature in males was $169.5 \mathrm{cms}(\mathrm{SD} \pm 6.569)$ and in females was $159.519 \mathrm{cms}(\mathrm{SD} \pm 5.859)$. 
In our study, we found that foot length showed statistically significant correlation with stature and so can be utilized for stature estimation. Thus, both in males and females, foot length is the best parameter for stature estimation.

In our study we found that the right foot length of males with correlation coefficient of $r=+0.761$, exhibits comparatively higher correlation with stature as compared to the left foot length of males with correlation coefficient $r=0.756$ and these correlations are statistically highly significant $(p<0.001)$. Thus right foot length is the better parameter than left foot length for estimation of stature.

Table 1:- Showing the relation of Foot Length with stature in males

\begin{tabular}{|c|c|c|c|c|c|}
\hline S No. & Population & Area & Author \& Year & r value & Linear regression equation \\
\hline 1 & Students & Mumbai & $\begin{array}{l}\text { Chikhalkhar BG } \\
\text { et al, } 2010\end{array}$ & 0.6102 & $\mathrm{H}=79.72379+3.650632 \times \mathrm{FL}$ \\
\hline 2 & Students & Delhi & Rani M et al 2011 & 0.808 & $\mathrm{H}=98.320+3.050 \times \mathrm{FLRT}$ \\
\hline 3 & Students & Maharashtra & Khanapurkar S \& Radke A, 2012 & 0.645 & $\mathrm{H}=90.0+3.2 \times \mathrm{FL}$ \\
\hline 4 & Students & Nepal & Mansur DI et al, 2012 & 0.688 & $\mathrm{H}=100.1+2.74 \times \mathrm{FLRT}$ \\
\hline 5 & General & Secunderabad & Babu RS et al,2013 & 0.583 & $\mathrm{H}=82.830+3.468 \times$ FLRT \\
\hline 6 & Students & Malaysia & Khairulmazidah M et al, 2013 & 0.697 & $\mathrm{H}=84.663+3.321 \times \mathrm{FLRT}$ \\
\hline 7 & Students & Nigeria & $\begin{array}{l}\text { Ozoko LEC, } \\
2013\end{array}$ & 0.779 & $\mathrm{H}=84.45+3.559 \times \mathrm{FL}$ \\
\hline 8 & Students & $\begin{array}{ll}\text { Kolar } & \text { Tamil } \\
\text { Nadu } & \end{array}$ & Dayananda R et al, 2014 & 0.636 & $\mathrm{H}=69.3663 \times \mathrm{FL}$ \\
\hline 9 & Students & $\begin{array}{l}\text { Madhya } \\
\text { Pradesh }\end{array}$ & Sutay S et al, 2014 & 0.688 & $\mathrm{H}=140.59+1.35 \times \mathrm{FL}$ \\
\hline 10 & Students & $\begin{array}{l}\text { Western } \\
\text { Nigeria }\end{array}$ & Tobias KE et al, 2014 & 0.7 & $\mathrm{H}=71.19+3.858 \times \mathrm{FL}$ \\
\hline 11 & Students & Puducherry & Rajesh DR et al, 2015 & 0.821 & $\mathrm{H}=98.159+3.746 \times$ FLRT \\
\hline 12 & Students & Mysore & Saharan RA \& Arun M, 2015 & 0.720 & $\mathrm{H}=101.95+2.6 \times \mathrm{FLLT}$ \\
\hline 13 & Students & GMC Jammu & Present study & 0.761 & $\mathrm{H}=58.4+4.41 \times \mathrm{FL}$ \\
\hline
\end{tabular}

Table 1 shows the various studies done for estimation of stature from foot length in males. A positive correlation is evident between foot length and stature in all the studies and ranges between 0.583 and 0.821 . The value of coefficient of correlation between stature and foot length in our study was found to be 0.761 . The results of our study were similar to a study done by Tobias KE et $\mathbf{~ a l}^{7}, \mathbf{2 0 1 4}$ where value of $\mathrm{r}$ was found to be 0.720 . Similar results were found by the study done by Saharan RA \& Arun $\mathbf{M}^{8}, 2015$ and Rajesh DR et al ${ }^{9}, 2015$.

In a study done by Babu RS et $\mathbf{a l}^{\mathbf{1 0}}, \mathbf{2 0 1 3}$ the correlation coefficient was found to be lower as compared to our study $(r=0.583)$. This difference could be attributed to the different genetic and environmental factors.

Table 2:- Showing the relation of foot length with stature in females.

\begin{tabular}{|c|c|c|c|c|c|}
\hline S. No. & Population & Area & Author \& Year & r value & Linear regression equation \\
\hline 1 & Students & Gujarat & Patel SM et al, 2007 & 0.80 & $\mathrm{H}=75.41+3.43 \times \mathrm{FL}$ \\
\hline 2 & Students & Delhi & Rani M et al, 2011 & 0.808 & $\mathrm{H}=90.207+3.374 \times \mathrm{FLRT}$ \\
\hline 3. & Students & Maharashtra & $\begin{array}{l}\text { Khanapurkar S \& Radke A, } \\
2012\end{array}$ & 0.702 & $\mathrm{H}=72.8+3.7 \times \mathrm{FL}$ \\
\hline 4 & Students & Nepal & Mansur DI et al, 2012 & 0.587 & $\mathrm{H}=96.31+2.66 \times \mathrm{FLRT}$ \\
\hline 5 & General & Turkey & Ozaslan A et al, & 0.496 & $\mathrm{H}=941.95+2.96 \times \mathrm{FL}$ \\
\hline
\end{tabular}




\begin{tabular}{|c|c|c|c|c|c|}
\hline & & & 2012 & & \\
\hline 6 & General & Secunderabad & Babu RS et al, 2013 & 0.66 & $\mathrm{H}=73.523+3.615 \times \mathrm{FLRT}$ \\
\hline 7 & General & Chennai & Kautilya VD et al, 2013 & 0.657 & $\mathrm{H}=83.24+0.337 \times \mathrm{FLRT}$ \\
\hline 8 & Students & $\begin{array}{c}\text { Ahmadabad } \\
\text { Gujarat }\end{array}$ & Parekh U et al, 2014 & 0.988 & $\mathrm{H}=63.62+3.61 \times \mathrm{FL}$ \\
\hline 9 & Students & Madhya Pradesh & Sutay S et al, 2014 & 0.587 & $\mathrm{H}=121.50+1.604 \times \mathrm{FL}$ \\
\hline 10 & Students & West Nigeria & Tobias KE et al, 2014 & 0.8 & $\mathrm{H}=73.15+3.578 \times \mathrm{FL}$ \\
\hline 11 & Students & Lahore & Malik AR et al, 2015 & 0.63 & $\mathrm{H}=88.210+2.93 \times \mathrm{FL}$ \\
\hline 12 & Students & GMC Jammu & Present study 2016 & 0.690 & $\mathrm{H}=69.7+3.83 \times \mathrm{FL}$ \\
\hline
\end{tabular}

Various studies for stature estimation from foot length in females have been done and a positive correlation between foot length and stature is seen in the table 2. Coefficient of correlation ranges from 0.496 to 0.988 . The value of correlation coefficient in our study was 0.690 . Our results were in consonance with a study done by Kautilya VD et $\mathbf{a l}^{5}, \mathbf{2 0 1 3}$ where value of $\mathrm{r}$ was found to be 0.657 . Similar results were also seen by studies done by Babu RS et al ${ }^{10}, 2013$,Malik AR et al $^{11}, 2015$ and Khanapurkar S \& Radke A, 2012 ${ }^{12}$ where the coefficient of correlation (r) was found to be $0.66,0.63$ and 0.702 respectively.

\section{Conclusion:-}

Stature determination from foot length of dismembered body parts is important for personal identification, especially when the utility of DNA analysis is limited because of economic issues or other difficulties, such as wars or mass disasters. The present study was taken up with the aim of finding out the correlation between dimension of foot with stature and also to derive a linear equation for the estimation of stature from these dimensions. So the present study explores the usability of dimensions of foot as predictor of stature in Jammu and Kashmir population.

Thus, the dimensions of foot can provide a good measure for estimation of stature of an unknown individual. The high correlation coefficient between the stature and foot length indicates that the foot length provides high reliability and accuracy in estimation of stature in both the sexes. So, this study could be helpful in medicolegal cases especially in identification of severed body parts in forensic and criminal identification. Also this study may be helpful in plastic and reconstructive surgeries.

\section{Conflicts Of Intrest:-}

There are no conflicts of interest.

\section{References:-}

1. Agrawal J, Raichandani L, Kataria SK, Raichandani S. Estimation of stature from hand length and length of phalanges. J Evol Med Dent Sci 2013;2(50):9651-56

2. Kozak J. Stature reconstruction from long bones. The estimation of usefulness of some selected methods for skeletal populations from Poland. Variability Evol 1996;5:83-94

3. Vernon DW, McCourt FJ. Forensic podiatry-a review and definition. Brit J Pod 1999;2(2):45-48

4. Parekh U, Patel R, Patel P. A study of relation of stature with foot length in natives of Gujarat state. J Med Sci 2014;3(1):22-25

5. Kautilya VD, Bodkha P, Poothanathan P. Determination of stature and sex from anthropometry of the foot among south Indians. Int J of Rev Life Sci 2013;3(2):22-26

6. Rani M, Tyagi AK, Ranga VK, Rani Y, Murari A. Stature estimates from foot dimensions. J Punjab Acad Forensic Med Toxicol 2011;11(1):26-29

7. Tobias KE, George MD, Vitalis E, Grillo DB. Sexual dimorphism of correlations of feet anthropometric parameters and height (stature) among undergraduate students of a university, western Nigeria. J Dent Med Sci 2014;13(4):46-53

8. Saharan RA, Arun M. Stature estimation from anthropometry in individuals above 18 years belonging to Indian demography. J Med Health Sci 2015;1(2):25-29

9. Rajesh DR, Chikkara P, Chokker VK, Singh A, Qadri SS, Kumar Y. Estimation of stature from foot dimensions and stature among south Indian medical students using regression models. J Krishna Inst Med Sci U 2015;4(1):95-99 
10. Babu RS, Deepika V, Potturi BR. Estimation of stature from foot length. Int J Pharm Biol Sci 2013;3(3):26670

11. Malik AR, Akther N, Ali R, Farrukh R, Aziz K. A study on estimation of stature from foot length. Prof Med J 2015;22(5):632-3

12. Khanapurkar S, Radke A. Estimation of stature from the measurement of foot length, hand length, head length in Maharashtra region. Indian J Basic Appl Med Res 2012;2(1):77-85 